\title{
Jak učitelé vnímají komunikaci s rodiči: Spokojení vs. vyhořelí
}

\author{
IDA VIKTOROVÁ
}

\begin{abstract}
Abstrakt: $V$ této studii jsme se zamérili na otázku, jak vidi komunikaci s rodiči učitelé dvou skupin na opačných pólech: spokojeni v profesi učitele vs. nespokojeni, resp. s rozvijejicim se syndromem vyhořenim. Zkoumali jsme totiž v rámci většiho projektu profesni nároky a syndrom vyhořeni u učitelù základnich škol. Jako jeden ze zdroju stresu ve škole je často uvádèna složitá komunikace mezi aktéry (učitelé, vedeni, žáci a rodiče). Vycházeli jsme z 58 rozhovorü s učiteli $z$ rüzných mist republiky. Výsledky ukázaly velmi rozdilný subjektivni obraz rodiču u tèchto dvou skupin. Vyhořeli učitelé maji vice konfliktù s rodiči žákü, mnohem hưre je proživaji a obtižněji hledaji jejich řešeni. Spokojeni učitelé jsou realističtějši, často konfliktưm prèdcházeji, maji pevnějši hranice komunikace a neproživaji problémy osobnè, rodiču se nebojí.
\end{abstract}

Klíčová slova: učitel základni školy, vyhořeni, komunikace s rodiči, konflikty s rodiči, řešení konfliktuis rodici.

\section{ÚVOD A TEORETICKÁ VÝCHODISKA}

Tato studie vychází $\mathrm{z}$ většího grantového výzkumu vyhoření a profesní zátěže u učitelů, ${ }^{1}$ který byl realizován na Katedře psychologie Pedagogické fakulty Univerzity Karlovy pod vedením Ireny Smetáckové ve spolupráci s l. lékařskou fakultou UK.

Práce s rodiči žáků je považována za významný zdroj učitelské profesní zátěže. Většina výzkumníkủ si na tomto poli všímá, že komunikace a konflikty, resp. malá podpora a úcta vyjadřovaná rodiči, jsou zřejmým zdrojem profesní nespokojenosti, stresu, nemocí i psychických problémů, vyhoření nebo odchodu ze školství (např̀ Lasky, 2000; Farber, 1982; Urbanovská, 2017; Pavlas Martanová \& Konůpková, 2019).

Podle českých i zahraničních výzkumů je učitelské povolání zatî̌žené velkým množstvím stresu (Kebza \& Šolcová, 2003; Žídková \& Martínková, 2003) a za nejsilnější stresory jsou považovány právě vztahy se žáky, rodiči, kolegy nebo vedením školy, výuka $\mathrm{v}$ heterogenních třídách a prestiž a ohodnocení učitelské profese. Pro vznik stresu však není důležité jen působení samotných stresorů, ale

\footnotetext{
${ }^{1}$ GAČR 16-21302S Učitelské vyhoreni - institucionálni, vztahové a intrapsychické faktory, 2016-2018.
} 
zejména jejich subjektivní zpracování konkrétním člověkem. Dlouhodobý a zejména nezpracovaný stres může vést ke vzniku syndromu vyhoření (Marek, Schaufeli \& Maslach, 2017; Kebza \& Šolcová, 2008), i když míra ohrožení u jednotlivých učitelů závisí i na dalších aspektech.

V našem výzkumu výsledky dokládají vysokou míru ohrožení učitelské populace základní školy (Smetáčková, Viktorová, Štech \& Ptáček, 2019). Žádné projevy vyhoření se neobjevily pouze u $16 \%$ vyučujících, velmi mírné projevy byly u $31,9 \%$, mírné projevy u $32,7 \%$, zřetelné projevy vyhoření byly zjištěny u 15,1\%, velmi silné projevy u 3,6\% a velmi závažné projevy u 0,7\%. Rozdíly mezi učiteli na prvním a druhém stupni základní školy nebyly významné. Tyto výsledky jsou bohužel horší nežli výsledky předcházejících výzkumů $\mathrm{v}$ českém prostředí (Kebza \& Šolcová, 2008; Urbanovská \& Kusák, 2009).

Vyučující s rozvinutým syndromem vyhoření nemohou reagovat dostatečně na obvyklé požadavky svého povolání; k žákům jsou lhostejní nebo je děti rozčilují, ztrácejí motivaci $\mathrm{k}$ práci, cítí se nedocenění a vyčerpaní, jsou více nemocní (Burke \& Greenglass, 1995; Kremer \& Hofman, 1985). S velkou pravděpodobností se tyto aspekty promítají nejen do práce s dětmi, ale také do komunikace $s$ dalšími lidmi, tedy i rodiči.

Komunikace $s$ rodiči, stejně jako výuka a vztahy s dětmi, tak mohou vystupovat ve dvou podobách: jako zdroj stresu a vyhoření - a současně jako jejich důsledek, jako selhávání v podobě konfliktů a problémů. Proto se téma subjektivního obrazu komunikace s rodiči u učitelů stalo výchozí otázkou pro tuto studii. Zjištuje souvislost mezi pracovní spokojeností, stresem a vyhořením na jedné straně a zvládáním či nezvládáním komunikace $s$ rodiči na straně druhé. $V$ našem výzkumu jsme totiž pracovali se dvěma skupinami učitelů. Těmi, kteří vykazovali vysoké skóre na škále vyhoření, a těmi bez silnějších příznaků únavy a stresu. Prozkoumání jejich situace v oblasti spolupráce s rodiči, o které jsme se všemi hovořili, se tak samo nabízelo.

Můžeme se současně dotknout otázky, zda za rostoucími pocity stresu u vyučujících může být i zhoršující se komunikace $s$ rodiči. Tedy zároveň $s$ otázkou na rozdíly mezi učiteli $\mathrm{v}$ oblasti komunikace $s$ rodiči je logické položit si otázku, zda i vnímání zhoršující se situace této komunikace je pravdivé a zda zahrnuje názory všech učitelů.

Původ nedorozumění mezi rodiči a učiteli je samozřejmě historicky včleněn do vzájemného vztahu obou institucí, především z důvodu odlišných funkcí, které v socializaci dítěte a také šíreji v transmisi kultury obě plní. Zjednodušeně řečeno slouží rodinná socializace $\mathrm{k}$ výchově individuálního jedince, zatímco školní socializace $\mathrm{k}$ výchově občana (Štech, 2007). Podobně se vyjadřuje i Možný, když kvůli rozdílným funkcím obou institucí - označuje vztahy mezi rodinou a školou za vztahy nepřátelské (Možný, 2004).

To ovšem samo o sobě nevysvětluje dostatečně stesky učitelů na narůstající požadavky rodičủ, jejich nevstrrícnost 
a agresivitu. Pavlas Martanová s Konůpkovou (2019) si všímají novějších trendů: nevhodný styl komunikace rodičů, obcházení učitelů přes další instituce, jako je vedení školy, poradenské instituce nebo inspekce, emoční náboj mnoha kontaktů $s$ rodiči, kdy je zpochybňována profesionalita vyučujících, dovednost učit a vychovávat, nutnost se neustále bránit a vysvětlovat své postupy nebo projekce chyb na stranu školy. Narůstá počet agresivních, nezralých a osobnostně patologických rodičů, resp. jejich projevů vůči škole.

Rabušicová s kolektivem (Rabušicová, Šed’ová, Trnková \& Čiháček, 2004) $\mathrm{v}$ přehledu modelů rodičovské spolupráce se školou reflektují spolu s názory dalších zahraničních výzkumníků obavu, zda nastupující modely „sdílené zodpovědnosti“, které dávají rodičům stále větší moc v rozhodování, nepovedou k narůstajícímu individualismu a vyhranění rozdílů mezi cíli školy a rodiny.

Podle Štecha (2007) dochází v posledních patnácti letech $\mathrm{k}$ jednomu $\mathrm{z}$ největších zlomů $\mathrm{v}$ historii školního vzdělávání. Tradičním významným úkolem školy bylo „vyvažovat tendence různých rodin poznamenaných narůstající profesní specializací i rozmanitostí a rozporností individuálních zájmů a spojit je $\mathrm{v}$ jeden společný úkol, kterým byla výchova občana, jak jsme již naznačili výše. Dnes sledujeme nadřazení individuálního zájmu společnému (srov. Kaščák \& Pupala, 2011). Výsledkem je, že se prosazuje svobodná volba rodičů, která znevýhodňuje ty rodiče, kteří neuplatňují tak silně svou moc, stydí se nebo neumějí prosazovat své individuální cíle (Šed’ová, 2009; Pulišová, 2016). I učitelé si všímají, že silní rodiče zvládnou zatlačit do defenzivy jejich ředitele i nadřízené orgány, a naopak jiní rodiče nejsou vyslyšeni, netroufají si na školu se obracet ani s vážnými otázkami nebo návrhy.

V této souvislosti se logicky mění role rodičů ve škole a jejich angažovanost, např. historicky nové role klienta nebo zákazníka vyplývající z posilování role rodičů ve škole. $\mathrm{V}$ souladu $\mathrm{s}$ tím rostou požadavky na role učitele, ve kterých se stále více objevují funkce sociální na úkor didaktických, resp. se didaktické role přizpůsobují heterogennímu žákovskému složení tř́íd. $\mathrm{K}$ tomu v poslední době zřejmě přispívá i větší sebevědomí rodičů a změny pohledu na funkce školy $\mathrm{v}$ kontextu inkluze. Rodiče mají pocit, že je třeba více prosazovat své zájmy, analyzovat potřeby svého dítěte a požadovat pro ně opatření ve výchovně vzdělávacím procesu ve škole. Možný si všímá v tomto kontextu narůstající nestability rodiny a s ní spojených problémů ve vztazích se školou. Nestabilita rodiny podle Možného naopak školu posiluje. Vědomí nejisté stability činí rodinu úzkostnějšś a někdy i agresivnější; u majetkově silných rodin pak přibývá arogance (Možný, 2004).

Takové posílení moci školy vůči rodině ovšem předpokládá jistotu a stabilitu na straně školy a učitelů. Proti oběma institucím stojí další vlivy, které situaci komplikují. Opět s odkazem na Možného je třeba si připomenout, že rodinu a její socializační sílu začala nahrazovat skupina 
vrstevníků, založená ve školní třídě. Tento stav oslabuje moc rodiny i školy, které se mohou dohodnout spolu přece jen lépe než s vrstevnickou partou (Možný, 2004). A dalším komplikujícím vlivem je tlak masových médií. Kaščák mluví o retroaktivní socializaci jako o oslabení role rodičů a dalších vychovatelů (dospělých) vůči dětem, protože jsou to děti, a nikoli rodiče, kteří táhnou vývoj a působí výchovně na starší generace (Kaščák, 2006).

Mnoha učitelům se nicméně daří pružně na změny ve školství a společnosti reagovat a produktivně jim čelit. Možná to však stojí více sil. Učitelé potřebují nové dovednosti, které jim dovolí obstát před rodiči. To vše vrací otázku po rozdílech mezi učiteli $\mathrm{v}$ tom, jak se jim daří $s$ rodiči pracovat a konstruovat smysluplně pro sebe i pro rodiče své vidění výchovy a vzdělávání svěrených dětí.

Právě proto, že dobrá spolupráce rodiny a školy ovlivňuje školní výsledky i práci dětí ve škole, je důležité si uvědomit, že mezi učiteli v jejich práci s rodiči jsou obrovské rozdíly. $Z$ toho důvodu jsme se pokusili podívat se na věc z pohledu učitelů, z hlediska profesní spokojenosti vyučujících a jejích důsledků na kontakt s rodiči.

Vztahům mezi rodinou a školou u nás je věnováno značné množství studií. Méně se ovšem sledují rozdíly mezi jednotlivými školami a jednotlivými učiteli. Pro naše potřeby si můžeme připomenout zejména zajímavou studii kolektivu autorů Rabušicové, Trnkové, Šedové a Čiháčka (2003), kteří se věnují právě rozdílům mezi školami ve spolupráci $s$ rodiči. Autoři sledovali školy, ve kterých jsou učitelé a rodiče spokojeni (resp. spíše spokojeni) se vzájemnou spoluprací. Z výzkumu plyne, že „postojové a názorové klima dané školy je daleko silnějším prediktorem spokojenosti se spoluprací - jak lidí ze školy, tak rodičů - než výčet realizovaných aktivit školy vůči rodičům a veřejnosti“ (Rabušicová et al., 2003, s. 114-115). Významná se ukázala míra otevřenosti školy, především to, jak jsou rodiče viděni. „Spokojené“ školy vidí rodiče jako zákazníky nebo dokonce partnery, a naopak učitelé $\mathrm{v}$ „nespokojených" školách vnímali mnohem silněji a častěji rodiče jako problém. K podobným závěrům dochází Matýsková (2005) př́i porovnávání škol s programem Začít spolu a běžných základních škol.

Naším cílem bylo zjistit, jak je téma spolupráce $s$ rodiči konstruováno individuálními učiteli, zda je vnímáno všemi jako závažné, zda jsou větší rozdíly v komunikaci s rodiči mezi učiteli ohroženými vyhořením a těmi relativně spokojenými a v jakých oblastech se projevují. Kontext školy zde vystupuje v podobě výběru respondentů, kdy z každé školy byli vybráni vždy dva a dva učitelé na opačném pólu výsledků na škále vyhoření.

\section{Metodologie}

Výzkumu, který měl část kvantitativní i kvalitativní, se zúčastnilo celkem 2394 vyučujících základních škol. Sběr dat probíhal prostřednictvím dotazníkové baterie, která zahrnovala standardizované i nestandardizované techniky. Syndrom vyhoření byl měřen prostřednictvím Shiromovy-Melamedovy škály vyhoření (dále jen SMBM) (Shirom \& Melamed, 2006). 
V tomto článku se soustředíme pouze na kvalitativní část představeného výzkumu. Ta byla realizována prostřednictvím 12 prrípadových studií škol v celé ČR, které využívaly kombinaci metod sběru dat: dotazníkové šetření mezi vyučující$\mathrm{mi}$, rozhovor s vedením školy, rozhovory s vybranými vyučujícími, analýza školních dokumentů a pozorování školního dění. Z 2394 učitelů, kteří se zúčastnili dotazníkového šetření, jsme pro rozhovory vybrali celkem 58 vyučujících z 12 sledovaných škol. Jednalo se především o ty učitele, kteří se umístili na opačných pólech škály vyhoření - vždy dva učitelé ohrožení vyhořením nebo vyhořelí a dva učitelé s absencí výskytu symptomů vyhoření měřeno na škále SMBM na každé škole. Tyto dvě skupiny učitelů bylo možné velmi dobře porovnávat a sebraná data se stala základním zdrojem materiálu pro další analýzu.

Rozhovory byly polostrukturované a poměrně komplexně sledovaly stránky profesní biografie a konkrétní školy, které mohou mít vliv na profesní spokojenost a vztahy ve škole - např. podoby spolupráce s rodiči, sociální oporu mezi kolegy, podporu vedení školy, podobu výuky a zájem o ni, profesní historii zaměřenou na prrípadnou genezi syndromu vyhoření či boj s ním, soukromí, volný čas apod.

Data byla analyzována kvalitativně tematickou analýzou s použitím zakotvené teorie. Jak uvádí Hendl (2005), při kvalitativní analýze jde o systematické nenumerické organizování dat $\mathrm{s}$ cílem odhalit témata, pravidelnosti, kvality a vztahy. Současně kvalitativní analýza dovoluje pracovat s četností jevů tak, aby zachytila sílu jednotlivých momentů a mohla je lépe propojit $s$ jejich subjektivními významy, což jsme často využívali.

Data z přepsaných rozhovorů s učiteli byla nejprve roztříděna pomocí programu Atlas. Získaný materiál, nyní již sloučený $\mathrm{k}$ tématu rodičủ, byl potom dále kódován ručně. Nové kódy skládaly další kategorie, které byly průběžně popisovány a organizovány do vzájemných vztahů, a tedy i stále revidovány, aby odpovídaly obsahům rozhovorů $s$ náležitou přesností, $s$ uvědoměním, že sledujeme subjektivní pojetí tématu respondenty. Opakované porovnávání kategorií vedlo $\mathrm{k}$ jejich vyčištění, kdy v prvním kroku se sledovaly popisované jevy a ve druhém jejich konstrukce a interpretace. Pro vytvoření systému kategorií jsme využili techniky vyložení karet a techniky kontrastování (Švaříček \& Šed’ová, 2007), kdy se jednotlivé kategorie nebo skupiny kategorií řadily proti sobě.

Výsledky jsme se rozhodli textově představit jako porovnání dvou skupin učitelů. Pro zjednodušení jsme pojmenovali první skupinu jako učitele spokojené a druhou jako učitele vyhořelé.

Potvrzením produktivního směru uvažování bylo zjištění, že mezi oběma skupinami jsou významné rozdíly a že uvažovat o práci vyučujících s rodiči v tomto kontextu má smysl. Rozdíly se projevovaly jak v praktikách (chování a postupy), tak v interpretaci a prožívání školních situací.

Mezi oběma hlavními skupinami byly rozdíly již na úrovni množství dat. Zpracovali jsme okolo 500 celků výpovědí o rodičích, které zmínili učitelé $\mathrm{v}$ rozho- 
vorech. Jedna výpověd’ měla rozsah jedné věty až dvou odstavců, které měly logickou souvislost. Spokojení učitelé celkově dosáhli menšího počtu výpovědí na jednoho učitele než vyhořelí. Nepřikládáme tomu až takovou váhu, protože rozdíly mezi výpověd'mi jednotlivých učitelů byly značné i uvnitř obou skupin. Je však možné opatrně konstatovat, že se vyhořelí vyučující věnují tématu rodičů více.

Přestože mluvíme o dvou skupinách, bylo zajímavým zjištěním, že spokojení učitelé si byli ve svém pojetí vztahu s rodiči mnohem blíže navzájem, jejich skupina se jeví mnohem koheznější. Naopak vyhořelí se v některých aspektech odlišovali mezi sebou navzájem více, a proto jsme je dále rozdělili do tři skupin: (1) vyčerpaní pečovatelé, (2) vystrašení v zákopech a (3) unavení cynici. Všechny tř̌i typy vyhořelých učitelů vykazovaly nejen vysoké skóre vyhoření, ale také další znaky jako únava, zklamání, velké množství neshod $s$ rodiči, které přerůstaly do konfliktů, potíže $\mathrm{v}$ organizování komunikace $s$ rodiči ad. Odlišovaly se však v některých jejich podobách, např. problematické hranice se u vyčerpaných a ustrašených vychylují do př́lišné volnosti, naopak u cyniků k výrazné nepružnosti.

Další odlišnosti mezi těmito třemi typy vyhořelých jsme našli $\mathrm{v}$ organizaci kontaktů $s$ rodiči, v interpretaci konfliktů a neshod, způsobech jejich řešení, v emocích a podobách př́běhů, které doprovázejí vnímání komunikace $s$ rodiči u jednotlivých typů. Celkově lze shrnout, že vyčerpaní pečovatelé chtějí pomáhat, vidí u rodin a dětí velké problémy, především sociální, ale nemají dost sil je řešit, nedostává se jim dobré zpětné vazby ani vděku. Vystrašení v zákopech mají z rodičů strach, čekají útoky a také všechny podněty ze strany rodičů tak čtou. Unavení cynici komunikaci podceňují, rozdělují rodiče a děti na ty, kterým stojí za to se věnovat, a na ty, u kterých to nemá cenu, rodiče někdy zastrašují.

Č́st kategorií byla generována relativně shodně oběma velkými skupinami učitelů, spokojenými i vyhořelými (např. existence neshod, vnímání podoby současné výchovy dětí, stres v povolání učitele nebo nárůst počtu problematických rodičů). Co však jednoznačně odlišovalo obě skupiny, bylo jejich prožívání. Rozdílné podoby prožívání komunikace s rodiči jsou signifikantním výsledkem našeho šetření. Např́iklad konflikty s rodiči zmiňuje většina učitelů obou skupin, ale vyhořelí učitelé je vnímají na rozdíl od spokojených se strachem, úzkostně a osobně.

Druhá část identifikovaných kategorií tvořila naopak proti sobě stojící jevy jako např. jistota proti nejistotě, dovednost předcházet konfliktům a řešit je proti pocitu být ve vleku situací, moc proti bezmoci, výčitky proti dobrým pocitům z práce, (ne)existence hranic, (ne)prítomnost prríběhů dokládajících obtíže s rodiči nebo organizace proti zmatku. Těchto kategorií bylo více a ukázaly obraz velkého rozdílu mezi oběma skupinami sledovaných učitelů.

Pro prezentaci výsledků jsou kategorie utř́íděny do trsů, které tvoří hlavní tematické oblasti: vnímání rodinné výchovy, podoby neshod nebo konfliktů s rodiči 
a jejich počet, organizace kontaktů $s$ rodiči, interpretace neshod a řešení problémových situací. Doplněny jsou o konkrétní citace jednotlivých učitelů s označením skupiny vyhořelých nebo spokojených učitelů.

\section{VÝSLEDKY}

\section{Současná rodinná výchova a (ne)- porozumění $s$ rodiči}

Většina učitelů zmínila současné, v jejich očích ne vždy žádoucí podoby rodinné výchovy dětí a její dopady do školy. $\mathrm{V}$ učitelském diskurzu rodiče nemají na děti dost času, umetají dětem cestu, obviňuji školu a učitele za všechny problémy a neúspěchy dítěte, mají nereálné požadavky nebo naopak neprojevují o školu vůbec zájem.

Učitelka - spokojená: „Dèti se hodně zmènily, tam je vlastně $i$ znát takovej ten vliv tý rodinný výchovy, prostě co chci, tak to bude, a nikdo mè nebude poroučet, co jako bych mél dělat, nebo takový, a myslim si ještě horši než ty děti, protože já učim proni, druhou trídu, že jo, takže tam vlastnè dèti utábnete na vařený nudli, co si budeme povídat, ale hroznè jako, zmènila se spolupráce $s$ rodiči. Jo, protože ty rodiče jako nechtěj jako spolupracovat, ignorujou nás."

Vyhořelí učitelé některé aspekty současné rodinné výchovy vnímají velmi intenzivně a dopady na vlastní výuku považují za zásadní až neřešitelné. Často srovnávají minulost se současnou situací a akcentují výrazné zhoršení rodinné výchovy i vztahu rodičů ke škole. Spo- kojení považují rodiče za realitu, se kterou je možné a nutné pracovat. Rozdíl mezi oběma skupinami učitelů je výrazný i v tom, jak velký vidí podíl problémových rodičů. Vyhořelí mají pocit, že jejich počet je značný a stále stoupá, spokojení jej považují za běžný. Př́íkladem tohoto rozporu jsou vyjádření učitelů, kteří pracují na stejné škole.

Učitelka - spokojená: „Samozřejmè, jsou tady situace, kdy ressime jako nepríjemný vèci s rodiči, ale zas si myslim, že vzhledem $k$ tomu, že treba máme jako do těch sedm set dětí, nebo víc než sedm set dètí, tak zas jako téch situací neni tolik, protože vopravdu to je vcelku jakoby v normé."

Učitel - vyhořelý: „Oni (rodiče) misto toho, aby řekli ditèti no tak se predved', jak to udèlás lepši, tak to prostě zpochybrnujou, jako kdykoliv se tyhle napomenuti udělujou, tak možná sedmdesát procent rodiču reaguje tim, že s tim jako ňák úplnè nesoublasí, no, má proti tomu nějaký výhrady."

\section{Realizace komunikace a aktivní hranice}

V komunikaci s rodiči tak, jak ji jednotliví učitelé konstruují, vystoupilo významně zejména téma hranic. U vyhořelých učitelů často pozorujeme nedostatečné hranice, a to na všech rovinách: ve formě, obsahu i času.

Pevné hranice ze sledovaných učitelů explicitně zmiňuje asi polovina spokojených, ale $\mathrm{v}$ mnoha dalších případech je implicitně nacházíme. Pokud jsou volnější, nejsou prožívány úkorně jako zneužívání od rodičů. $U$ vyhořelých učitelů se 
setkáváme častěji s volnějšími hranicemi a jejich důsledky jsou prožívány nepř́ijemně. U vyčerpaných je to př́lišnou pracností a nevděkem rodičů, u ustrašených obavou z povahy komunikace. Cyničtí mají většinou hranice stanoveny pevně $s$ odkazem na zbytečnost komunikace $s$ těmi, „kterým to nepomůže“.

Učitelka - vyhořelá: „Večer v pưl devátý o jarnich prázdninách volala (maminka). Že si toho všimla v bakalárich té poznámky a zarazilo jí to, já jsem ríkala: Já jsem jako na horách, ráda to s váma jako proberu, ale prostè ta poznámka byla oprávnèná, protože vyrušovala. A pak takový: ,No, vy jste ríkala, že poznámku dáte týhle a napsala jste ji i mý dcerí. A já ríkám: ,Heledte se, jako nebudu všem ř́kat v hodinè, komu napišu poznámku, oni védí, jak se chovaj, jak se maj chovat, jak se nechovaj, jsou v sedmé trídè. Pak to teda pochopila asi po patnácti minutách jakoby rozhovoru, takže to mě zarazilo, že i takhle obtěžujou."

Učitelka - spokojená: "Jako védi, že na SMSku já jako nereaguju, máme jasný pravidla. Ráno omluvěj, védi, když SMSka odešla, tak nebudu psát ok. Jo a co se týce voláni, tak prostě máme vymezenej nějakej čas, rikám pred tou školou... A taky jako, to jsme si fakt řekli jako pravidla, já jim taky telefonuju, když s nima potřebuju mluvit. Vètšinou to, co počká, tak si pišem pres informačni knižku."

Hranice se týkají také typu témat směřujících $\mathrm{k}$ aktivnímu řešení. Zvláště vyčerpaní pečovatelé mají tendenci řešit situace za hranicemi učitelské role, prožívají hluboce potíže dětí i jejich rodin. Spokojení učitelé drží snadněji hranice profesionality, jejich očekávání jsou reálná a předcházejí vědomě možným potížím, jak uvidíme v následující citaci.

Učitelka - spokojená: „A rozhodně se nenechám vláčet tím, že bych ve dne v noci myslela, jak oni tam mezi sebou bojuji, to ne. Ditě vyslechnu vždycky... A mně nedělá problém pohladit, pochovat, když je $z$ toho to dité opravdu rozčarované a smutné. Ale tu situaci si musi vyřresit oni. Protože takový prípad ve trídé mám a bylo to velmi těžké nezachraňovat to ditě, které někde má maminku a tatinka. Jako zachrañuji, ale do určité hranice. Už to bylo tak, že v podstaté byste pak kupovala školni pomuicky a platila divadla, když rodina nefunguje. Pak to šlo oficiálni cestou, obrácenim na sociálku. A dostanete se do toho, že kryjete tu maminku."

$\mathrm{V}$ jedné škole, kterou navštěvují sociálně slabší děti, dokonce musel ředitel nařídit stanovení hranic sám. A učitelé, mnohdy vyčerpaní pečovatelé, je museli prrijmout, jak vidíme na výseku $\mathrm{z}$ rozhovoru:

U: „No ted'už mi nevolaji. Ale když vidim zmeškaný hovor, tak zavolám zpátky."

$V:$ "Rodiče na vás mají telefon?"

U: "Maji, vsichni."

$V:$ "A proč ríkáte: ted' už mi nevolaji?"

$U:$ "To bylo to, jak jsme rešili s panem reditelem, kam ažjsem ty rodiče pustila a že by se ty emaily mély stopnout."

Ani u spokojených učitelů nemusíme najít vždy pevné hranice ve všech případech, rozdíl je ovšem v tom, že učitel se necítí kontakty rodičů přetížený, prožívá je volně a reaguje podle potřeby. Naopak vyhořelí vyučující komunikaci prožívají 
špatně, ale pravidla nestanovují, diví se „nevhodnému chování" rodičů, očekávají, že rodiče pochopí sami, jak se mají chovat, a jsou uražení nebo znepokojení, protože se tak neděje.

\section{Konflikty, jejich interpretace, prožívání a dopady na řešení}

Problémy v komunikaci s rodiči se objevují relativně často u všech sledovaných učitelů. Rozdíl mezi vyhořelými a spokojenými je však zásadní. Vyhořelí učitelé zmiňují opakované, velké a mnohdy neřešitelné problémy $\mathrm{v}$ komunikaci $s$ rodiči. Spokojení učitelé se s nimi setkávají méně a úspěšněji je řeší. Značná část spokojených vyučujících explicitně uvádí, že nemá žádné problémy s rodiči, ani je neměla nikdy v minulosti. Podobná skupina se u vyhořelých vůbec nevyskytla.

Učitelka - spokojená: „Tak, co se týká mè osobnè, tak já sem konflikt, za tèch patnáct let jako prímo konflikt neméla. Akorát jednou na mě priběbla maminka, že jsem si dovolila dát holce čtyřku na vysvědčeni, ale to jsme vyřešily prostě na chodbè, rikám: trváte na ňákým přezkoušeni? Netrvala, tak (smich) zase odešla. A jednou, že jsem nechala ñáký ditè po škole, eee, ale to bylo úplnèv samým začátku, jinak jsem já konflikty s rodiči teda neméla."

Učitelka - spokojená: „Že když já zavolám, a to já se stim nemažu, takže když jakejkoli problém, byt' i že reknu podivejte se, najednou začal mit blbý známky, neděje se nèco? Všechno je v pořádku? Jestli se nic nedèje, tak to prostě začal flákat, dupnète na nèj, a prostě ta komunikace tam jako funguje, to jako bez debat. A ty rodiče choděj do práce, takže když budou třikrát do mésice chodit do školy, tak to je prostě na nic. Ale $v$ okamžiku, kdy sem príjdou, tak s nima na rovinu jednám, prostě vysvětlit jim, že to jejich díté je v jejich zájmu i v mým, aby se mèlo co nejlip, aby nejlip prospivalo, aby makalo. A vétšinou to tak funguje."

Konflikty jsou u spokojených také méně osobně prožívány, přestože i zde se setkáváme se stresem, strachem nebo obavami, které provázejí situace s konkrétními rodiči. Na rozdíl od vyhořelých najdeme i rozvahu, humor a radost $\mathrm{z}$ řešení.

V rámci základních charakteristik komunikace s rodiči jsme u spokojených učitelů nacházeli kategorie jako předcházení konfliktům, dovednost $\mathrm{v}$ komunikaci, společný postup, dohoda a vyjednávání. Pokud se vyskytne nějaká neshoda s rodiči, což se děje i spokojeným vyučujícím, doprovází je spíše informace o dobrém výsledku, o spokojenosti s řešením a prrípadné nevyřešení konfliktu není bráno nijak tragicky. $\mathrm{Na}$ opak u vyhořelých učitelů se často setkáváme s konflikty, které nejsou dořešeny, objevuje se pocit bezmoci v práci s rodiči nebo rozčarování z výsledku, který nevyhovuje.

Vyhořelí učitelé nemluví nikdy přímo o předcházení konfliktům jako o dovednosti, ale spíše ve smyslu alibi ze strachu. Rodiče jsou vylíčeni $\mathrm{v}$ některých př́ípadech (nejčastěji u ustrašených v zákopech) jako vnější nepřítel, komunikaci s nimi doprovázejí obavy, zklamání a úzkosti.

Učitelka - vyhořelá: „Zažila jsem konfikt. Měla jsem holčinu, která mèla nevlastního otce a jednou na mè priš́el a šel mi vyhrožovat. A to byl takovej konflikt, že holka 
doma lhala a rodiče věrili jí. Přepisovala si doma známky a tak. A ten tatínek, když mi prìšel vyhrožovat do tý školy, tak to i pan reditel ř rel, že bych mohla podat trestni oznámeni. Ale neudèlala jsem to. Jsem si řekla, že si nebudu ničit život kvůli někomu. Takže tyhle rodiče mě dokázali opravdu hodně ničit. To bylo asi nejhorši moje trauma ze školy, který jsem zažila."

Učitelka - vyhořelá: „Mám hrůzu z té komunikace preses e-mail, protože mi prijide, že ta hra se slovy je dost nejistá, že néco napisete nèjak, někdo to pochopi a pak se vám z toho může vyvinout hrozně dlouhá debata."

Učitelka - vyhořelá: „Necejtím se bezpečnè nebo i jistè, fakt máte strach."

Můžeme si všimnout, že interpretace problémů je odlišná a - což je velmi důležité - má př́ímý dopad na způsoby řešení školních situací. Práce $s$ problémy totiž odpovídá konstrukci jejich vzniku, jejich subjektivnímu obrazu v očích učitelů. Ten je potom $\mathrm{v}$ logickém souladu s postupy řešení nebo reakce.

Ustrašení učitelé $\mathrm{v}$ zákopech produkují legendy o zločinech rodičů, pocitují strach a nutnost stálé ostražitosti a obrany. Nátlak rodičů nevnímají jako podnět $\mathrm{k}$ zamyšlení a řešení, protože na zločiny není třeba reagovat, jen se jim bránit. Problémové situace proto většinou neřeší a nechávají běžet. Potřebují častěji pomoc vedení nebo kolegů. Opuštění profese zmiňují explicitně tř̌i vyučující z této skupiny. Jedna učitelka během výzkumu dokonce tak učinila.

Učitelka - vyhořelá: „A ted,' to mě tedy úplnè dostalo, že jsme méli nějakou stižnost a řrešilo se to pres i policii a takhle, takže to rodiče napsali i na českou školni inspekci, ono to bude odloženo, a ještě zvažuje paní ucitelka, který se to týká, zvažuje podáni trestniho oznámeni za pomluvu a za krivé výpovédi a nevím co všechno, a to si myslim, že by měla udělat. Ale hlavně oni podali trestni oznámeni, že osahávala chlapečka, a já ríkám, že to je profesně dost velký prưšvih, protože kdyby nedej bože musela zmènit práci, což se stane... tady ne, protože tady policie rekla, že to je jasná msta, že neshledávaji nic, ti to odložili, a oni to poslali ještè vlastně na inspekci, takže se to znovu šetrìlo, ale ze všech materiálù, co jsme mèli $k$ dispozici, tak se ta inspekce, ty materiály, které vyzkoumaji, daji právnikovi a on jenom jako ten právnik se $k$ tomu jako vyjádrí z hlediska práva. Žádný emoce, žádný věci. To je strašny!"

Vyčerpaní pečovatelé mluví o velkých problémech, které nemají řešení, nepřichází vděk ani náprava. Reší různé situace i za hranicí učitelské role, ale mnohdy nezvládají složitou pomoc rodičům časově ani energeticky, a jsou navíc zklamaní $\mathrm{z}$ nedostatku vděku a výsledků. Přesto většinou nepřestávají pomáhat, pracují s diskutabilními výsledky, ale s obrovským nasazením, které je také prrícinou jejich problematického psychického nebo zdravotního stavu.

Učitelka - vyhořelá: "Já si myslím, no, jako spousta tèch dètí, je mi jich strašnè lito, protože to vyloženě některý pocházi z nepodnètnýho prostredí, že to jsou dèti, který jsou casto prostè ponechaný na pospas, tak nevim, spiš se mi třeba osvédčilo, že když s nima člověk promluví nebo se jich na nèco zeptá z jejich osobniho života nebo nějak se 
trošku odpoutá od tý školni problematiky, že se dá $k$ nim nèjak trošku proniknout, jako některý jsou prostě obèti svých rodičù, rodin a viubec by nemusely dopadat tak jak dopadaj, a vidím, že ta škola je mele, mele, jsou neúspěsný, jak nemaj tu podporu, tak vlastně permanentní neúspéch."

Unavení cynici vidí problémy na straně rodičů, někdy zmiňují i skandály (podobné legendám u vystrašených, nikdy však tak rozsáhlé), které je opravňují, aby pracovali jen $s$ těmi, kteří si to zaslouží. Cynici odmítají často př́emýšlet nad vzniklou situací, protože není třeba do některých lidí dávat svou energii. Řešení tak často vyhovují především jim samotným.

Spokojení učitelé mluví častěji o konkrétních problémech, které vyřešili. Pomoc vedení někdy dokonce odmítají jako zbytečnou, jindy ji prííímají, pokud ji považují za spravedlivou pro všechny aktéry. Spokojení učitelé celkově neshodám více předcházejí, střízlivě a přiměřeně reagují na situace nazrálé $\mathrm{k}$ řešení. I oni se setkávají s konflikty a nevhodně řešenými situacemi. Právě ty nás upozorňují na reálné potíže, se kterými se dnes musí vyporáádat všichni učitelé. Všichni občas pocitují bezmoc a zklamání. Přesto se spokojení učitelé rychleji se svými pocity vypořádají, vnímají situace reálně, a pokud lze, volí vhodná řešení.

Jen málo učitelů, jak spokojených, tak vyhořelých, si všímá rodičů, kteří mlčí, nevystupují s požadavky, ale chodí do školy a starají se o dítě a školní povinnosti. Spokojení mají pocit, že všichni rodiče jsou vcelku bezproblémoví, cyničtí se domnívají, že rodičovské pocity nejsou jejich starost. Vystrašení v zákopech jsou rádi, že je tito rodiče neohrožují. Jsou to však kupodivu právě oni, kteří si těchto rodičů všímají nejvíce. Unavení pečovatelé je berou jako všechny ostatní, pokud cítí, že jim mají pomoci, ale protože nemají dost sil, častěji je přehlížejí.

Učitelka - vyhořelá: "Já si myslim, že to je porád ňáká obava, že se bojej, že za to budou potrestáni, nebo já nevim najednou zjistime, že sebrali ditè a priblásili ho na jinou školu a v podstatě nevime proč a nemáme sanci to napravit, jo? Pak reknou, no my si, my tam jezdíme do práce, ale pak se stejnè dozvime, že to bylo z nějakýho dưvodu, že se tady na toho chlapečka nèkdo špatně podival, jo, ale nemáme šanci $k$ nápravé jakoby, jo. Ale jinak si myslim, že pak když už dojde $k$ ñákému otevrenému hovoru, tak zase nékteři jsou vstrícnějsìi."

\section{DisKUSE A ZÁVĚR}

Představené výsledky považujeme za zajímavé. Vzhledem k tomu, že ve výzkumu, ze kterého jsme vycházeli (Smetáčková et al., 2019), se zjistilo, že velké množství vyučujících je přímo ohrožených vyhořením, je obraz zásadně rozdílné povahy práce $s$ rodiči důležitým ukazatelem problémů našeho školství. Při analýze dat to mnohdy vypadalo, že se jednotlivé kategorie naprosto rozpadají do dvou oddělených polí, které vytvořily obraz spokojeného nebo naopak vyhořelého učitele $\mathrm{v}$ práci $s$ rodiči. Připomínáme, že nejde jen o vnímání komunikace a očekávání chování rodičů, ale především o množství nevhodně realizovaných 
školních situací. Především poukazujeme na situaci zcela odlišného prožívání komunikace s rodiči, které je jedním ze zdrojů stresu, kdy spokojení učitelé nemají významné potíže s rodiči, ale vyhořelí, zvláště ve skupině ustrašených, jich popisují velké množství, navíc bez vhodných vyústění. Př́rćina a následek tak vytvářejí opakující se cyklus.

Některé komunikační charakteristiky vyhořelých učitelů bychom mohli dokonce vnímat jako ukazatele stupně vyhoření. To, že naši učitelé $\mathrm{v}$ souvislosti $s$ rodiči dokonce uvažují o opuštění profese, je problematické i v širším kontextu. Řešení vidíme v posílení podpory učitelů, supervizi nebo jiném sdílení zkušeností, v dobrých vztazích učitelů a vedení školy, $\mathrm{v}$ ochraně učitelů od nadřízených orgánů apod. Školám by pomohlo vyjasnění kompetencí učitelů a ředitelů škol vůči rodičům a jejich požadavkům. Nejde přitom pouze o zdraví a spokojenost učitelů, ale také o dopady na jejich práci, kdy víme, a náš výzkum to jen akcentuje, že vyhořelý učitel není schopen dobře učit, reagovat vhodně na požadavky dětí a jejich rodičů (srov. Smetáčková et al., 2019)

Jak upozorňuje Štech (2007), Kaščák a Pupala (2011). Možný (2004) nebo Rabušicová a kol. (2004), je současná situace učitelů dosti problematická, což se nám ve výzkumu potvrdilo. Individuální požadavky rodičů jsou sice v liberální společnosti pochopitelné, ale nejsou vyváženy žádnou zodpovědností $\mathrm{k}$ učitelům nebo ostatním rodičům, jejich dětem a jejich potřebám. To se i v našem výzkumu ukazuje relativně silně. I spokojení učitelé po- pisují nevyhovující komunikaci s rodiči, jejich malou podporu a narůstající počet těch, se kterými se obtížně domlouvají. $\mathrm{Na}$ druhé straně cítíme u spokojených učitelů kompetence přesvědčit rodiče o dobrém působení školy, o svých učitelských dovednostech. Dávají tak rodičům dostatek jistoty, jsou schopni číst mnohdy nejasné rodičovské obavy i ataky a produktivně s nimi pracovat.

Naše výsledky nejsou $\mathrm{v}$ zásadním rozporu se studiemi Rabušicové s kol. (2003) nebo Matýskové (2005) a dalších, které sledovaly spokojenost se vzájemnou komunikací rodičů a učitelů v kontextu celých škol. Dobrá atmosféra, dobré vztahy uvnitř školy a otevřenost $\mathrm{k}$ rodičům ovlivňuje celkovou spokojenost všech. Naši vyhořelí učitelé jeví podobné individuální charakteristiky jako školy s malou spokojeností v komunikaci s rodiči. Také jsou málo otevření a partnerští $\mathrm{k}$ rodičům, brání se jim nebo je odmítají, nebo se jim naopak př́lišs podřizují. Sledovaní vyhořelí učitelé všech tří typů neberou rodiče jako partnery ke spolupráci, dokonce zřejmě ani jako zákazníky nebo klienty. Náš výzkum ukazuje na jejich malou sebejistotu, menší důvěru ve své dovednosti, v možnost spolupráce, malou důvěru v podporu uvnitř školy, což se v situaci zvýšené nejistoty rodičủ coby vychovatelů ukazuje jako stále významnější požadavek na učitelskou profesi.

Výzkum měl samozřejmě některá omezení. Školy, na kterých probíhaly př́ípadové studie, $\mathrm{z}$ nichž čerpáme data pro tento text, byly z hlediska míry vyhoření (měřené škálou SMBM) lepší než ostatní školy v celkovém skóru vyhoření. 
Také vytvoření dvou skupin učitelů na základně výsledků z dotazníku vyhoření, zde označených jako spokojení a vyhořelí, znamenalo poněkud rozdílné hodnoty tohoto skóru u jednotlivých učitelů, protože vystupovalo v kontextu školy - a školy se navzájem značně odlišovaly. Právě tyto okolnosti, jako vliv školy jako celku, by zasluhovaly samostatnou studii. Tyto skutečnosti však neměly zásadní vliv na představená data.

Přes určitá metodologická omezení výzkumu považujeme výsledky za inspirativní, zejména hlubokou odlišnost práce s rodiči u učitelů spokojených a vyhořelých, jejich prožívání a řešení situací s rodiči.

\section{Literatura}

Burke, R. J., \& Greenglass, E. (1995). A longitudinal study of psychological burnout in teachers. Human Relations, 48(2), 187-202.

Farber, B. A. (1982). Teacher burnout: Assumptions, myths, and issues. Based on a paper presented at the Annual Meeting of the American Psychological Association, Washington, DC. ED 22936. Hendl, J. (2005). Kvalitativni výzkum: základni metody a aplikace. Praha: Portál.

Kašćák, O. (2006). Moc školy. O formativnej sile organizácie. Bratislava: Veda.

Kašč́k, O., \& Pupala, B. (2011). Škola - statický element v sociálnej dynamike. Úvodní stat. In O. Kaščák \& B. Pupala (Eds.), Škola - statický element v sociálnej dynamike (s. 6-14). Bratislava: Iura Edition. Kebza, V., \& Šolcová, I. (2003). Syndrom vyhoření. Praha: Státní zdravotní ústav.

Kebza, V., \& Šolcová, I. (2008). Hlavní koncepce psychické odolnosti. Československá psychologie, 52(1), 1-19.

Kremer, L., \& Hofman, J. E. (1985). Teachers' professional identity and burn-out. Research in Education, 34(1), 89-95.

Lasky, S. (2000). The cultural and emotional politics of teacher-parent interactions. Teaching and Teacher Education, 16(8), 843-860.

Marek, T., Schaufeli, W. B., \& Maslach, C. (2017). Professional burnout: Recent developments in theory and research. Routledge.

Matýsková, D. (2005). Spolupráce rodiny a školy z pohledu rodičů a učitelů. Pedagogická orientace, 15(1), 27-36.

Možný I. (2004). Česká rodina pozdní modernity: nová podoba starého partnera a rivala školy. Pedagogika, 54(4), 309-325.

Pavlas Martanová, V., \& Konůpková, O. (2019). Odlišné světy učitelů a rodičů: interakce s rodiči jako zdroj stresu učitele. Pedagogická orientace, 29(2), 223-242.

Pulišová, K. (2016). Neklape nám to: učitelé a rodiče žáků prvního stupně základních škol a jejich problémové vztahy. Studia paedagogica, 21(3), 67-182.

Rabušicová, M., Šedová, K., Trnková, K., \& Čiháček, V. (2003). O školách, v nichž jsou rodiče i ředitelé spokojeni se vzájemnou spoluprací. SPFFBU, Studia paedagogica, U8, 103-116.

Rabušicová, M., Šedová, K., Trnková, K., \& Čiháček, V. (2004). Škola a (versus) rodina. Brno: Masarykova Univerzita. 
Shirom, A., \& Melamed, S. (2006). A comparison of the construct validity of two burnout measures in two groups of professionals. International Journal of Stress Management, 13(2), 176-189.

Smetáčková, I., Viktorová, I., Štech, S., \& Ptáček, R. Vztah syndromu vyhoření, copingových strategií a self-efficacy mezi vyučujícími na českých základních školách. Československá psychologie 63(4), 386-401.

Šedová, K. (2009). Tiché partnerství: vztahy mezi rodiči a učitelkami na prvním stupni základní školy. Studia paedagogica, 14(1), 27-52.

Štech, S. (2007). Profesionalita učitele v neoliberální době. Pedagogika, 57(4), 326-337.

Švaříček, R., \& Šedová, K. et al. (2007). Kvalitativni výzkum v pedagogických védách. Praha: Portál.

Urbanovská, E. (2017) Vztah rodičů a dětí jako faktor ovlivňující vzdělávání dětí se zdravotním postižením. Paidagogos, 2016(2), 141-153.

Urbanovská, E., \& Kusák, P. (2009) Syndrom vyhoření učitelů ve vztahu k vybraným determinantám. E-Pedagogium, IV, 108-121.

Žídková, Z., \& Martinková, J. (2003). Psychická zátěž učitelů základních škol. České pracovní lékaŕství, 4(3), 6-10.

PhDr. Ida Viktorová, Ph.D.

Pedagogická fakulta Univerzity Karlovy, Katedra psychologie;

e-mail: ida.viktorova@pedf.cuni.cz

\section{VIKTOROVÁ, I. How Teachers Perceive Communication with Parents: Satisfied vs. Burned-out}

In this study, we focused on the question of how communication with parents is seen by teachers of two groups at opposite poles: satisfied in the profession of teacher vs. dissatisfied, and actually with developing burnout. We examined the professional demands and the burnout syndrome of primary school teachers as part of a larger project. The complexity of communication between stakeholders (teachers, leadership, pupils and parents) is often cited as a source of stress at schools. We started from 58 interviews with teachers from various places in the Czech Republic. The results showed very different subjective forms of parents in the two groups. Burned-out teachers have more conflicts with parents, experience them in a much worse way, and often struggle to solve them. Satisfied teachers are more realistic, they often prevent conflicts, and do not experience problems in person.

Kewords: primary school teacher, burnout, communication with parents, conflicts with parents, solving conflicts with parents. 